The University of Maine

\title{
DigitalCommons@UMaine
}

2016

\section{Decoupling and Displaced Emissions On Swedish Consumers, Chinese Producers and Policy to Address the Climate Impact of Consumption}

Cindy Isenhour

University of Maine, Department of Anthropology, cynthia.isenhour@maine.edu

Follow this and additional works at: https://digitalcommons.library.umaine.edu/ant_facpub

Part of the Environmental Policy Commons, Environmental Studies Commons, International Economics Commons, International Relations Commons, Political Economy Commons, and the Social and Cultural Anthropology Commons

\section{Repository Citation}

Article title: Decoupling and Displaced Emissions On Swedish Consumers, Chinese Producers and Policy to Address the Climate Impact of Consumption Article reference: JCLP5008 Journal title: Journal of Cleaner Production Corresponding author: Dr. Cindy Isenhour First author: Dr. Cindy Isenhour Final version published online: 6-AUG-2016 Full bibliographic details: Journal of Cleaner Production (2016), pp. 320-329 DOI information: 10.1016/j.jclepro.2014.12.037 


\title{
Decoupling and displaced emissions: on Swedish consumers, Chinese producers and policy to address the climate impact of consumption
}

\author{
Cindy Isenhour ${ }^{a, *}$, Kuishuang Feng ${ }^{b}$ \\ a Department of Anthropology, University of Maine, Orono, ME 04469, USA \\ b Department of Geographical Sciences, University of Maryland, College Park, MD 20742, USA
}

\section{A R T I C L E I N F O}

\section{Article history:}

Received 14 August 2014

Received in revised form

10 December 2014

Accepted 11 December 2014

Available online 23 December 2014

\section{Keywords:}

Sustainable consumption

Climate policy

Decoupling

Efficiency

Sweden

China

\begin{abstract}
A B S T R A C T
New developments in consumption-based emissions accounting suggest that the reductions claimed by wealthy, environmentally progressive nations have often come at the expense of increased emissions elsewhere - and thus net growth in global GHG concentrations. This paper traces Sweden's attempts to translate growing recognition of displaced emissions into national environmental policy. Drawing on multi-sited ethnographic research and policy analysis in Sweden and China, we argue that while the logical implications of consumption-based analyses point to the need to address production and consumption as an integrated system, complex governance challenges and the political precariousness of these ideas have thus far limited policy to the reinvention of consumer awareness campaigns and an international extension of long-standing ecological efficiency efforts. We argue that consumption-based emissions indicators justify more ambitious demand-side policy response.
\end{abstract}

(־) 2014 Elsevier Ltd. All rights reserved.

\section{Introduction: the climate impact of consumption}

Concerned about climate change, many nations have responded with mitigation efforts focused on improving domestic energy efficiencies - often with notable success (Weidner and Mez, 2008; EEA, 2013). However, a large and growing body of research has documented the cannibalization of these domestic improvements by sustained growth in consumption and the emissions embedded in international trade (Munksgaard et al., 2002; SEPA, 2012c). More disturbing, many lend empirical support to the assertion that national efforts to decouple economic growth from ecological harm can result in displaced environmental impact and net growth in global emissions (Peters and Hertwich, 2008; Peters et al., 2011).

Drawing on these findings, this paper addresses the significant climate impact of what the European Environmental Agency (EEA, 2012b) has suggested is the "mother of all environmental issues"; consumption. As living standards and ideologies of need continue to "ratchet up" (Shove, 2004) in both developed and developing economies, the emissions embodied in internationally traded consumer goods are increasingly significant drivers of global GHG

* Corresponding author. Department of Anthropology, University of Maine, 5773 S. Stevens Hall, Orono, ME 04469-5773, USA. Tel.: +1 303 807 6515; fax: +1 207581 1823. concentrations. Peters and colleagues (2011b) argue that $28 \%$ of global emissions are already embodied in international trade, a portion that is only projected to increase with intensified globalization and market liberalization (Sato, 2012).

While there have been significant advancements in methodologies to analyze the climate impact of growing consumption levels and carbon-rich international supply chains (Davis and Caldeira, 2010b; Davis et al., 2011; Peters et al., 2012, 2011; Wiedmann, 2009), efforts to incorporate these insights into international negotiations have been marginalized (see Atkinson et al., 2011; Carmondy, 2009; Isenhour, 2012; Mattoo et al., 2009; Petherick, 2012). National policies to address the climate impact of consumption are also extremely rare (Broadhag, 2010) due to the complex governance challenges presented by global supply chains. Only a few nations have measured the global impact of their consumption, and even fewer have attempted to utilize them to inform climate policy (Barrett et al., 2013).

This paper traces one such effort in Sweden - the first nation to officially recognize the displaced climate impact of their consumption. We explore how this wealthy and environmentally progressive nation has attempted to translate these findings into politically viable environmental policy. The Swedish case has significant international relevance given that Sweden is internationally celebrated as a successful example of ecological-economic decoupling, a strategy that has been highlighted as a significant 
policy goal in both the EU's 7th Environmental Action Plan (EEA, 2013) and in international discussions about the "green economy" (UN 2012).

Yet consumption-based emissions indicators challenge claims that economic growth and ecological harm can be absolutely decoupled. Instead, they point to the need for "strong sustainable consumption" policies that move beyond improving the efficiency of consumption to address consumer demand and reduce absolute material and energy consumption (Lorek and Fuchs, 2013). It is widely recognized that ecological modernization's focus on efficiency and neoliberalism's focus on consumer choice have combined to dominate sustainability rhetoric and practice, but that they do very little to address issues of environmental justice, rebound effects or growing global consumption levels.

Our analysis of policy formation in response to these concerns is based on ethnographic and mixed-methods research in Sweden and China between 2007 and 2014. Data include analysis of Swedish and EU policy documents published between 2008 and 2014 as well as interviews with 35 representatives of 25 Scandinavian governmental and non-governmental organizations including the Swedish EPA, Ministry for the Environment and Consumer Agency. To animate this policy formation process and associated challenges, we focus particular attention on Sweden's efforts to lend technological assistance to the People's Republic of China. We thus also incorporate research on Sino-Swedish climate cooperation which included additional policy reviews, secondary research and interviews with three Swedish and two Chinese climate policy analysts in Stockholm and Beijing during the summer of 2012 and 2014.

Our argument proceeds as follows: we begin with background and a theoretical rationale for the Swedish case - highlighting both domestic and international claims that Sweden has successfully decoupled economic growth from ecological harm. The second section traces Sweden's attempts to translate a growing awareness of displaced emissions into policy through: 1) domestic mitigation and efficiency improvements, 2) consumer education and 3) international policy specifically via technological transfer to producer-nations such as the People's Republic of China. The fourth section discusses our findings relative to recent debates about the need for strong sustainable consumption policy. Our conclusion reiterates the argument that our understandings of displaced emissions and the climate impact of consumption justify more ambitious demand-side policy than it has generated to date - in Sweden and abroad.

\section{Swedish decoupling and global markets: theory and background}

Sweden is internationally celebrated as a positive example of economic-ecological decoupling, or the effort to separate economic growth from ecological harm. According to Kyoto reporting requirements, the state's emissions taxes and significant investments in technological improvements have resulted in a $20 \%$ reduction in GHG emissions since 1990 (SEPA, 2013). While this accomplishment is notable in itself, state documents emphasize that these reductions were achieved during a period of significant overall growth. Between 1990 and 2010 efficiency measures and simultaneous economic growth resulted in a $72 \%$ reduction in the carbon intensity of the national economy (SEPA, 2012a, TCO 2012), leading many in Sweden and abroad to declare decoupling an overwhelming success, one worthy of international replication (OECD, 2004; UNEP, 2011) (Fig. 1).

During the last decade, however, there have been significant improvements in and a subsequent "explosion" (Carmondy, 2009) of robust consumption-based environmental indicators that call into question claims of successful decoupling (EEA, 2014). These include tools to measure per capita water (Hoekstra and Mekonnen, 2012), biodiversity (Lenzen et al., 2012) and nitrogen use (Leach et al., 2012). More central to our discussion here is the significant refinement of research on carbon footprints (e.g. Berglund, 2011; Sato, 2012) and a growing number of increasingly robust databases, analytical tools and studies which account for the emissions embedded in international trade (Davis et al., 2011; Peters and Hertwich, 2008; Peters et al., 2011).

In contrast to the production-based emissions inventories used in the UNFCCC reporting processes, which account for GHGs released within a given set of geo-political boundaries, consumption based emissions capture both direct and indirect emissions associated with the goods and services a nation's citizens consume (e.g. Davis and Caldeira, 2010b; Feng et al., 2013; Peters et al., 2011), regardless of where they were produced (domestic electronics, toys from China, clothing from Bangladesh or beef from Argentina). The total global emissions are essentially the same, but the consumption-based method sheds light on emissions drivers (Peters et al., 2012) and suggests an alternative distribution of responsibility. As Dawkins and her colleagues write, "territorial emissions tell us where the emissions occur, but the consumption approach tells us why the emissions occur. Increasing demand for

Decoupling of GHG Emissions from GNP

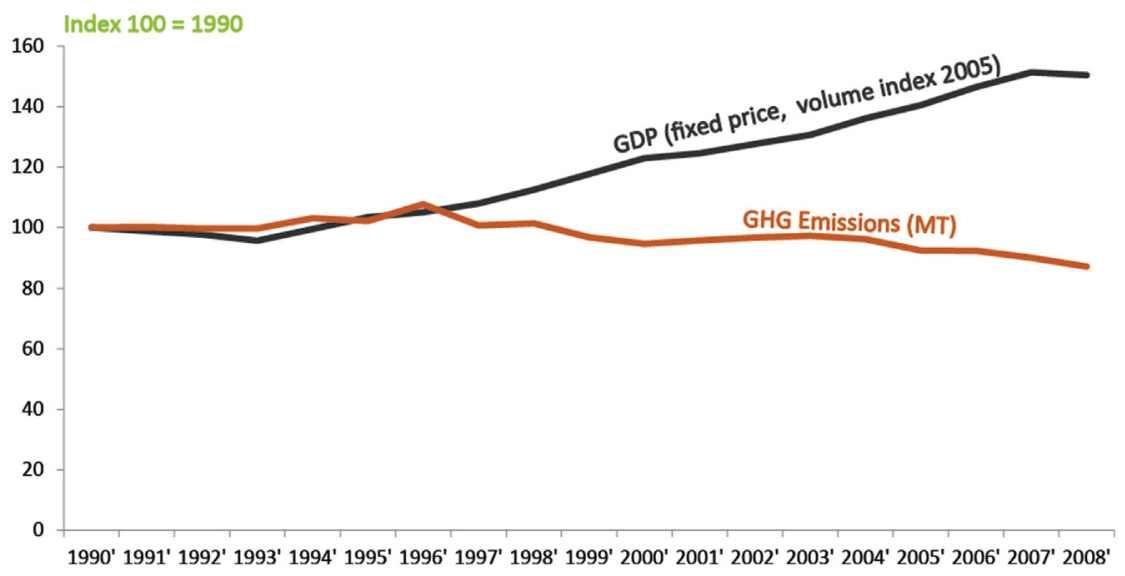

Fig. 1. Swedish decoupling of GHG from GNP. 
products and services drives up emissions around the world" (2010:1).

As the carbon intensity of the Swedish economy has improved over the last several decades, scholars and environmentalists have noted a strong parallel trend - significant growth in household disposable income. During the 20th century Swedish consumption expenditures doubled nearly every thirty years (SEPA, 2012d). Between 2000 and 2008 alone growing consumer demand in Sweden contributed to a 40\% increase in imports (SEPA, 2012b:15). This phenomenon is mirrored in several wealthy and environmentally progressive European economies (Barrett et al., 2013, Petherick, 2012). The European Environmental Agency estimates that while domestic efficiencies resulted in reduced direct energy use within the EU-27 between 2000 and 2007, overall resource use per person increased by $9.1 \%$, largely due to an increase in the per capita consumption of indirect energy, resources and emissions embodied in imported consumer goods (EEA, 2012a).

Increased awareness of the global climate and environmental impact of production and consumption led Sweden's Environmental Objectives Commission to propose in 2008 that,

“,...it is essential to change patterns of production and consumption, not only in Sweden, but in large parts of the world. It is proposed that Statistics Sweden should be commissioned to develop indicators to measure the environmental impacts of Swedish consumption in other parts of the world" (2008:10).

The proposal was approved and, in November of the same year the Swedish EPA released a report entitled Konsumptionens Klimatpåverkan, translated in 2010 with the English title "The Climate Impact of Swedish Consumption." The report found that, in contrast to previous production-based emissions reports which suggested that Swedish GHG emissions were below 1990 levels, consumption-based accounting revealed that growing consumer demand had contributed to a $25 \%$ increase in emissions over the same time period. Several international organizations including the EU and OECD have joined Sweden and a handful of other nations to adopt consumption-based research perspectives (Csutora and Mózner, 2012). Their findings suggest average consumption-based emissions are $11 \%$ higher than production emissions in the EU 27 (Boitier, 2012) and 16\% higher among OECD countries. In highly affluent and environmentally progressive nations like Sweden and the UK, these differences exceed 30\% (OECD, 2013).

The Swedish EPA report certainly called into question the "win-win" claim that resource efficiencies and economic transitions have resulted in a true decoupling of economic growth from the ecological base (Berglund, 2011). Instead, the data provide support for a "zero-sum", world-systems scenario in which environmental improvements and economic accumulation in one region were made possible by displacing the fulfillment of consumer demand and the responsibility for associated pollution into another (Bergman 2013; Berglund, 2011; Deitz and O'Neill, 2013; Hornborg, 2009; Jackson, 2009; Mills and Waite, 2009; Sjöström and Östblom, 2010; Stern, 2004). Channeling Harvey, we refer to this process as "accumulation by displaced emissions". Several scholars have illustrated that emissions reductions are linked to weak carbon leakage (Bruckner et al., 2010; Erickson et al., 2012; Peters, 2008; Peters et al., 2012; Peters and Hertwich, 2008 Sato, 2012). In this process environmental damage is displaced due to a deeply unequal global system, a dual shift in wealthy and environmentally progressive economies toward both dematerialized industry yet increasingly materialized lifestyles, and the associated movement of environmentally damaging industries into countries with fewer labor protections and environmental regulations.
In the context of globalization, which geographically separates consumers from the environmental impacts of their lifestyles, Gupta has written, "transnational trade is one of the most effective ways to transmit the ecological costs of overconsumption onto others" (1998:304). In 2010 these perspectives on ecologically uneven exchange (Foster, 2000; Hornborg, 2009; Martinez-Alier, 1987) and the climate impact of rising levels of consumption made their way into Sweden's national system of 16 measurable and closely tracked environmental objectives which were modified to include an overarching "generational goal" which states,

"Our goal is to hand over to the next generation a society in which the major environmental problems in Sweden have been solved, and that this should be done without increasing environmental and health problems outside Sweden's borders" (SEPA 2010:1).

The Swedish EPA was tasked with developing indicators for measuring progress toward the generational goal (SEPA, 2012a). As the environmental objectives commission (2013:1) stated,

"Policy instruments and measures to solve environmental problems in Sweden must be designed to ensure that Sweden does not export environmental problems ... this calls for an ambitious environmental policy - in Sweden, in the EU and in international contexts"

Yet as acknowledged by the Swedish EPA, understanding how to measure and achieve progress toward this goal "has not been selfevident" (SEPA, 2012c). Not only is it quite difficult to measure the environmental impacts of complex global supply chains, but states like Sweden have few means by which to influence production and environmental practices overseas, particularly if acting unilaterally and without sparking trade disputes. Curious to see how the ambitious generational goal might unfold we traced the development of policy designed to support it through a series of iterative interviews with environmental advisors at the Swedish EPA, the Environmental Ministry and through a review of policy documents published by these agencies between 2008 and 2014. The next section outlines our findings.

\section{Results: from knowledge and the "Generational Goal" to policy}

While the original mandate for the 2008 Swedish EPA report on the climate impact of consumption included the development of policy recommendations to compliment the descriptive data, the scope was administratively revised by the head of the EPA. According to one of the report's authors, the EPA was concerned that including policy recommendations would make the report too political, even in Scandinavia where strong mainstream environmentalism is well documented (European Commission, 2009a, 2009b; Gullestad, 1989; Löfgren, 1995; Micheletti, 2003).

This prediction was likely correct given that the descriptive research proved to be contentious. When the findings were presented at the Swedish EPA's annual Climate Forum in 2008, a representative of Sweden's Centre Party vociferously critiqued the report, calling it anti-market and a threat to the sustainability of the Swedish economy. Another leader with the Ministry for the Environment argued that the problem was not with Sweden's laudable and ambitious investments in efficiency gains, but rather "dirty production in China".

Similar contentions around consumption-based approaches have arisen in other national contexts (Petherick, 2012; Public Interest Research Centre, 2011). In 2012 the UK Parliament published a report in which they expressed concern that the UK was 
meeting their domestic carbon budget at the expense of increased global emissions. The government quickly dismissed these findings stating that they did "not agree ... rather, the UK's domestic achievements contribute to global progress" (Parliament, 2012: 1). Further, climate officials argued that a shift toward consumptionbased emissions could derail the UN climate negotiations or cause an "absolute firefight" (UK House of Commons Environmental Audit Committee, 2011). Indeed, contentions surrounding consumption-based approaches remain widespread. Sato (2012:24) writes, that "Attempts in public policy to deviate away from the conventional production-based carbon accounting approach to account for EET [emissions embodied in trade] has been met with hard opposition." Certainly this opposition is as diplomatic as it is ideological given the challenges of influencing global supply chains without violating sovereignty or trade agreements.

Nonetheless, there is a growing movement to start translating the insights of consumption-based approaches into public policy at varying scales. Barrett and colleagues' (2013) suggest that consumption-based accounting be used alongside production- and territorial-based metrics. The authors argue that in the absence of universal carbon policy (which does not seem likely at least in the short term) consumption-based emissions accounts are most appropriately used at the state level to: help set emissions targets; formulate policies to encourage more sustainable domestic consumption patterns; and to establish international trade policy. Similarly the EU's Sustainable Consumption and Production program outlines a three-pronged approach: improving domestic production efficiencies; educating for more sustainable consumer choice; and providing technological assistance to developing nations.

Sweden's response to date has closely mirrored these suggestions. The following three sub-sections of this paper outline movements toward 1) more ambitious emissions targets and energy efficiency programs; 2) consumer awareness campaigns and voluntary programs designed to improve the efficiency of contemporary consumption patterns and 3) international policy specifically via technological transfer to producer-nations such as the People's Republic of China. In each section we also present the barriers associated with these strategies and critically analyze - in light of empirical sustainable consumption research - the likely efficacy of each.

\subsection{Strategy one: emissions targets and energy-efficiency improvements}

Sweden has long invested in creating an economy built on sustainable energy and its efficient use. According to the International Energy Agency (IEA) Sweden is a global leader in both lowcarbon intensity and proportion of renewables in total energy supply. The Agency writes, "this is the result of continuous political efforts: a stringent carbon dioxide and energy taxation, emissions trading and the promotion of renewable energies" (2013:9).

Interviews with policy analysts at the Swedish EPA and representatives of the Swedish Environmental Ministry suggest that the consumption-based emissions report played at least an informal role in setting future efficiency and emissions targets - largely because it helped to raise awareness of the need to set more ambitious goals to offset the emissions embedded in trade. At the time of writing, Swedish targets mandate an additional $20 \%$ reduction in energy intensity by 2020 and a 40\% reduction in GHG emissions by the same year, a more ambitious plan than that recently promised by the EU. The IEA and Swedish government suggest that the state is well positioned to achieve this transition through "cost-effective market-based measures, consumer benefits and technological innovation" (IEA 2013:10). Yet many studies suggest that the current emphasis on improved resource efficiencies, in Sweden and internationally, is unlikely to result in absolute global reductions in resource use and associated environmental impacts since efficiency gains tend to result in lower prices, making additional production and consumption more attractive (Jenkins et al., 2011), and given a significant increase in imports.

In order to avoid these "rebound effects" the Swedish EPA has recognized the need to compliment domestic efficiency improvements with a greater focus on demand-side policy, writing "so far, policy instruments to mitigate the environmental impacts of consumption and production have focused primarily on ... product manufacture" (2012d:86). We argue, and the EPA has recognized, that technology "will not be enough" without "comprehensive" life-style changes - a trend reversal that calls for "political resolve" (SEPA, 2012c: 26). Over the past decade, growing recognition that efficiency improvements are being rapidly outpaced by growth in the emissions associated with household consumption has led to an increased policy emphasis on educating for individual consumer responsibility and sustainable lifestyles (Matti, 2009, Isenhour, 2010a,b).

\subsection{Strategy two: consumer awareness and the rationalization of contemporary lifestyles}

In Sweden, demand-side policies have focused on increasing consumer awareness and developing incentives designed to "nudge" individuals to voluntarily make better choices on the market (e.g. turning off the lights, efficient appliances, green appliances and alternative transport) (Isenhour, 2010b; Matti 2009). Many Swedes have responded. As a citizenry Swedes are relatively sensitive to climate concerns (EC, 2013) and messages about consumer responsibility (Isenhour, 2010a,b). In 2013 81\% of Swedes responded that climate change was the most serious problem facing the world, compared to $50 \%$ for the rest of the EU (EC, 2013). More recently $100 \%$ of Swedes agreed that protecting the environment is important and $96 \%$ believe that they can play a role (EEA, 2014). Given this high level of engagement and perceived self-efficacy, one might expect more sustainable consumption patterns to emerge - if anywhere - in Sweden.

Certainly awareness efforts and voluntary programs like ecolabels are positive in many ways (Spaargaren, 2003) but a significant body of research suggests that decades of consumer awareness campaigns have failed to produce sustainable consumption patterns in Sweden or elsewhere. Scholars have long observed that heightened levels of awareness and pro-environmental attitudes do not always translate into sustainable behavior (Ölander and Thøgersen, 1995). Even highly aware and committed consumers are inconsistent, ambivalent, confused and conflicted (Halkier, 2001; Isenhour, 2010b; Sassatelli, 2006). There is also significant evidence to suggests that consumers are already overwhelmed by an abundance of information and choices (Shreck, 2008; Wilk, 2010). The preconditions for sustainable consumption are often not in-place and significant barriers get in the way (World Council for Sustainable Business, 2008).

Perhaps more disturbing, pro-environmental behaviors don't always translate into appreciable reductions in environmental impact (Alfredsson, 2004; Connolly and Prothero, 2008; Wilk, 2010). Csutora's 2013 study, for example, compared the ecological impact of "brown" consumers, who don't report environmental concern or action, with "green" consumers. She found that despite significant differences in awareness and behavior, there was no clear pattern in ecological impact. Similarly Alfredsson, using an extensive database of 1000 Swedish households, concluded that 
household adoption of "green consumption" does not appreciably reduce GHG emissions without reductions in total consumption since families often reallocate efficiency-generated savings to the purchase of goods with higher embedded emissions (2004).

These findings are not presented to suggest that consumer education, awareness and action aren't, like efficiency gains, also important. They are crucial for building policy legitimacy (Halkier, 1999) and provide essential "gestures of change" that can drive more significant actions (Sassatelli, 2006). But it is to say that the movement toward educating for voluntary market-based consumer responsibility will likely not be enough. Certainly policy makers and marketers cannot expect consumers to take on the responsibility of ensuring sustainability if there are barriers that even those who are educated, aware and engaged cannot overcome (Isenhour, 2010a, b; Press and Arnould, 2009; Wilk and Wilhite, 1984). Policies are needed to address these barriers and ensure that all consumers can reduce their impact rather than placing the burden for environmental welfare on a minority of committed individuals.

Drawing on an analysis of the drivers and barriers to proenvironmental behaviors in Sweden (Söderholm, 2011), the Swedish EPA also acknowledged in a 2012 report that "information is not enough" (2012d). The agency noted that educational programs and informational labels are individualizing while environmental problems require a collective approach, applied equally to all citizens in order to eliminate feelings of inequality, relative depravation or incentives to free ride. Similar conclusions have been reached by consumption scholars (Ölander and Thøgersen, 1995) and the UK government which concluded, "non-regulatory measures used in isolation including nudges, are less likely to be effective" (Hobson, 2013a citing UK House of Lords 2011:5).

Despite this widespread recognition of the need for more aggressive demand-side policy by sustainable consumption scholars and a growing number of policy makers, notions of consumer choice, freedom and sovereignty are so thoroughly engrained (Wilk, 2010), that policies which seek to move beyond voluntary choice are unpopular (Attari et al., 2009). John Barrett has argued that most governments, regardless of "political persuasion" do not have a "strong appetite" for taxing or restricting the sale of carbon intensive products. As such national level policies designed to reduce or redirect consumer demand remain almost "entirely absent, both in Sweden and in other countries" (Naturvårdverket, 2011). Further, efforts to define "a sustainable level of consumption and how to achieve it are typically not well understood by policy makers, business leaders or the general public" (Allaway, 2012: 18).

Barret argues, "There might be a greater justification for technology transfer being funded by developed countries, because China would argue that a third of its emissions are exported" (Rees, 2011:1). Given the "sociopolitical unpalatability" (Hobson, 2013a: 1084) of addressing growing consumption levels and standards of living at home, the Swedish government has, as Barrett predicted, recently directed significant efforts up the supply chain by providing technological assistance to developing producer countries. These efforts are intended to address the energy and carbon intensity of the goods and services Swedes import rather than domestic consumption levels.

\subsection{Strategy three: "Taming the dragon" through SINO-SWEDISH climate cooperation}

While Sweden engages in environmental technology transfer in a wide array international contexts, we focus here on Sino-Swedish exchange. As the world's largest absolute emitter of $\mathrm{CO}_{2}$ emissions, China is under significant pressure to reduce emissions. Indeed, it is common to hear politicians cite China as "the real source of the

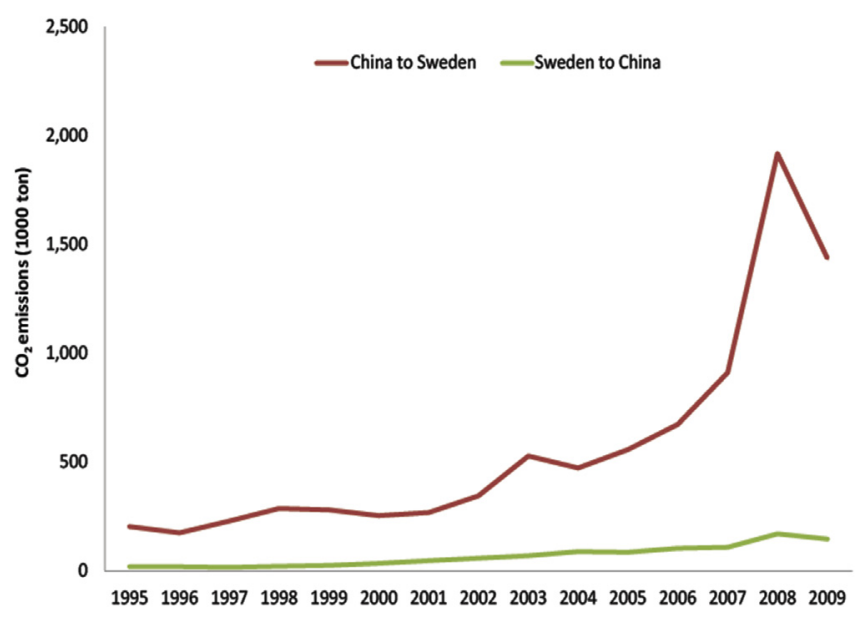

Fig. 2. $\mathrm{CO}_{2}$ emissions embedded in Sino-Swedish trade 1995-2009.

climate problem" as did the official at the 2008 Climate Forum in Stockholm. During interviews in Sweden, a representative of the Swedish Environmental Ministry suggested the need to, as he phrased it "tame" the Chinese dragon. His analogy was extended further through several references to $\mathrm{CO}_{2}$ emissions as "dragon breath". Certainly China has a significant role to play. An analysis by the International Energy Agency suggested that Chinese national policy could result in approximately $25 \%$ of the global emissions reductions necessary by 2020 (IEA, 2009).

However, it must also be recognized that a significant share of China's emissions are associated with production for foreign companies and of goods and services bound for foreign markets. Sato's review of consumption-based emissions suggests that, between 22 and $45 \%$ of China's emissions are associated with exports (2012). Drawing on these carbon exchanges, China has openly expressed support for the inclusion of consumption-based emissions in international climate negotiations. Foreign Ministry spokesman Qin Gang stated "The developed countries move a lot of manufacturing industry into China. A lot of the things you wear, you use, you eat are produced in China. On the one hand, you shall increase the production in China, on the other hand you criticize China on the emission reduction issue" (New York Times, 2007).

To illustrate the carbon imbalance in Sino-Swedish trade we ran an environmentally-extended multiregion input output (MRIO) analysis of $\mathrm{CO}_{2}$, utilizing data from the World Input Output Database (Fig. 2). ${ }^{1}$ Our analysis shows that between 1995 and 2009 the $\mathrm{CO}_{2}$ emissions released in China but associated with Swedish consumption rose by more than $600 \%$. While the trade-embedded emissions associated with Swedish exports to China also increased during the same time period, there remains a significant trade imbalance for which China is currently held responsible. One must also keep in mind these figures are only associated with SinoSwedish trade. When all international trading partners are accounted for, consumption in highly developed economies like Sweden's results in a significant international displacement of emissions and a carbon burden for producer countries.

\footnotetext{
1 The MRIO approach is a consumption-based accounting procedure that captures both direct and indirect emissions associated with consumption of a product, business, region, or nation (See detail in Murray and Lenzen 2013). The approach has been applied in many studies on calculating consumption-based $\mathrm{CO}_{2}$ emissions and embodied carbon in supply chains at both subnational, national and global scales (e.g. Davis and Caldeira, 2010; Feng et al., 2013; Peters et al., 2011). In this study, global MRIO tables sectoral level $\mathrm{CO}_{2}$ emissions from 1995 to 2009 are collected from WIOD database (WIOD 2012).
} 


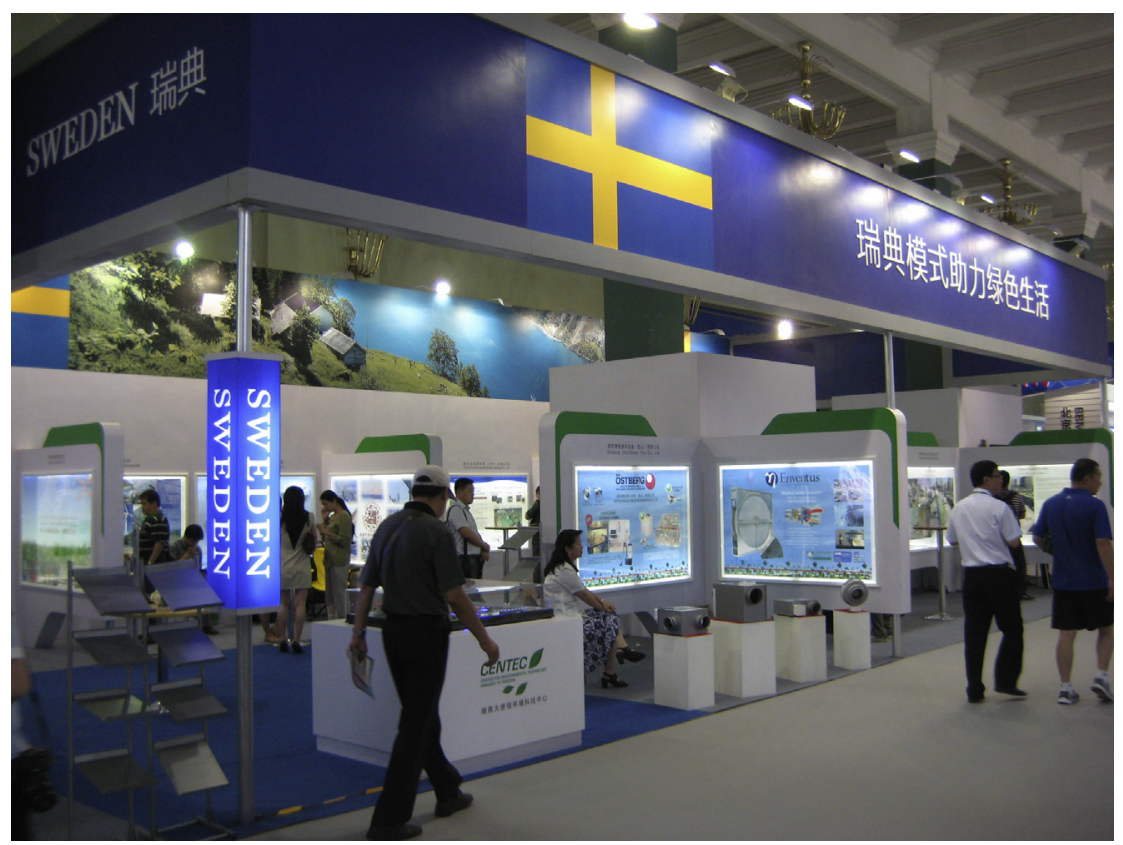

Fig. 3. The Ambassador explains Swedish enviro-tech at EnerChina 2014. Photo Author, Beijing 2014.

The authors of The Climate Impact of Swedish Consumption (2008/2010) have suggested that their estimates of consumptionbased emissions are likely conservative given that many Swedish imports come from their closest trading partners in Europe -yet many of these products were previously imported from nations with much more carbon intensive production (SEPA 2010). While we focus on imports from China in this analysis, we use it only as an illustration to animate the policy formation process. Swedish imports increased by $40 \%$ between 2000 and 2008 - with products linked to emissions released not just in China, but all over the globe.

The Swedish State, having recognized: 1) that growing consumption levels were cannibalizing domestic efficiency gains and contributing to net growth in global emissions; 2) the political and trade-based difficulty of limiting the consumption of carbon intensive products among its citizenry; and 3) the inability to achieve the generational goal without addressing either domestic consumption levels or the carbon intensity of the products they import - has implemented an aggressive program to provide international environmental technology assistance. While Sweden is investing in energy efficiency technology transfers in a number of international contexts we focus here on China, where Sweden has invested significant effort.

Sweden and China share a deep history of bi-lateral partnership, dating back to 1847 when the two nations signed an agreement on trade and friendship. Perhaps more importantly, Sweden was the first western nation to recognize and develop diplomatic relations with the People's Republic of China in the 1950s. Building on this strong history of cooperative partnership, the Swedish government set up the Center for Environmental Technology (CENTEC) at their Embassy in Beijing with funding from the Swedish International Development Cooperation Agency (SIDA). The Center's mission focuses on promoting and facilitating Chinese and Swedish exchange of "envirotech" in both the private and public sectors. According to SIDA the overall objective of the center was to "contribute to the decrease of carbon dioxide emissions in China and to improve the living conditions at large" (Froberg et al., 2013:8), but the Swedish EPA has also stated that envirotech exports and SIDA's funding for technological exchange helps to reduce the impact of Swedish consumption abroad.
CENTEC has helped to facilitate several cooperative agreements. During a state visit by Prime Minister Reinfeldt in 2008 and a visit from the Swedish Environment Minister in 2013, important relationships were solidified leading to the establishment of working groups for cooperation on sustainable urban development and energy efficiency.

CENTEC facilitated the export of Swedish environmental technologies valued at approximately 37 million USD ${ }^{2}$ between 2008 and 2012 (Froberg et al., 2013:8). Some high profile Swedish environmental technology transfer "success stories" include energy efficient ventilation systems in Beijing's iconic CCTV tower and a highly efficient heat pump in the Olympic Village. ${ }^{3}$ But as the former CENTEC director quickly points out, this is just a small piece of the picture as it doesn't account for trade which occurred without CENTEC facilitation or transfers made through the Clean Development Mechanism. Indeed the export of environmental technologies has been seen as a key area of growth for the Swedish state, one that is consistent with the concept of a "green economy" designed to achieve economic growth while contributing to the development of less damaging systems of production and consumption. In 2007 alone Swedish environmental technology exports totaled approximately 4.8 billion USD (Fig. 3 ). ${ }^{4}$

This assistance is also consistent with China's increasingly ambitious energy efficiency and decoupling goals. While China's emissions growth was staggering in the first decade of the 21st century, largely due to coal exploitation, in 2009 China announced a target to reduce the carbon intensity of their economy by $40-45 \%$ of 2005 levels and to use non-fossil fuels for approximately $15 \%$ of its primary energy consumption by the end of 2020. During China's 11 th five year plan they achieved a $19 \%$ reduction in energy intensity and have set a goal for the 12th Five Year Guidance to reduce $\mathrm{CO}_{2}$ emissions per unit of GDP by $17 \%$. President Xi Jinping, who rose to power in 2012, has affirmed a commitment to these

\footnotetext{
${ }^{2}$ Calculated via Forex 5 year average exchange rate 2008-2012 of 6.93.

${ }^{3}$ For additional Swedish enviro-tech success stories visit http://www. swedenvirotech.se/en/china/Success-stories/?c=energy.

4 Calculated via Forex average exchange rate for 2007 of 6.75 .
} 
improvements, at least in rhetoric, stating that China "will not sacrifice the environment for short term economic gain" (Xinhua News Agency, 2013). Chapter 21 of the current five year guidance states that the plan will:

"Reasonably restrict energy consumption, decrease the growth of industries with high energy consumption, and increase energy efficiency. The plan will strengthen energy conservation assessment responsibilities, complete energy-saving regulations and standards, improve market mechanisms and implement pivotal energy-saving projects ... In addition, it will persist in common but differentiated principles of liability and vigorously launch international cooperation in response to global climate change" (BCCC 2011)

In this policy document and others, China clearly emphasizes the "common but differentiated responsibilities" framework set up under the Kyoto protocol which called on developed nations to act first to reduce emissions - given their historical responsibilities for atmospheric carbon concentrations and developing nations' right to development. While the United Nations is currently working toward an undifferentiated and "legally binding" framework and the US and China have recently signed a deal to limit emissions, Chinese policy has long encouraged foreign governments to utilize the Clean Development Mechanism (CDM). This tool provides developed countries the opportunity to meet emissions targets by investing in cost-effective projects in developing countries.

China hosts the largest CDM market in the world. By 2011 the PRC's National Development and Reform Commission (NDRC) had approved more than $3000 \mathrm{CDM}$ projects, constituting $42 \%$ of all registered projects internationally (Buhr et al., 2012). Most interesting with regard to our point here is that the Chinese government placed significant priority on energy efficiency improvements. Due to this emphasis the number of energy efficiency CDM projects has increased rapidly, by tenfold since 2006 (Buhr et al., 2012).

International technological diffusion is certainly positive in many ways. It allows Sweden to work toward its generational goal by influencing, even if indirectly, the carbon intensity of the products and services it imports. Further, it can do this in a cooperative way, without the complex governance challenges associated with unilateral border adjustment taxes or domestic restrictions on carbon-intensive products which could potentially damage demand for products from developing contexts.

Yet the focus on international technological assistance raises a familiar set of critical questions about whether or not efficiency improvements (international and domestic) can result in a decoupling of economic growth and environmental deterioration without addressing rapid consumption growth. As the Chinese State aggressively works to encourage urbanization and the development of domestic markets, significant growth in consumption is projected. Certainly many Chinese citizens desperately need to consume more and the nation has a right to development. However, it is reasonable to ask if Sweden's attempt to counteract the climate impact of their own consumption through the diffusion of energy efficient technologies into China simply rationalizes accelerated consumption and a globalized rebound effect.

Tim Jackson argues it is essential to make a clear distinction between "relative" and "absolute" decoupling. Relative decoupling, for which there is some evidence, refers to $\mathrm{CO}_{2}$ per unit of GDP but only tells us that emissions have been reduced relative to economic growth. Relative decoupling doesn't necessarily tell us anything about net reductions or "absolute" global reductions of $\mathrm{CO}_{2}$. Jackson writes that for absolute decoupling to work "resource efficiencies must increase at least as fast as economic output" (2009:70, emphasis ours).

Global emissions of $\mathrm{CO}_{2}$ associated with fossil fuel combustion have increased by 80 percent since 1970 . In 2012 the amount of $\mathrm{CO}_{2}$ in the atmosphere grew by 2.2 parts per million, a rate of change greater than the growth in the previous ten years combined (WMO, 2013). In order to achieve the emissions reductions needed to avoid exceeding two degrees of change, Jackson has modeled the global technological improvements given .7\% annual population growth and $1.4 \%$ annual income growth. He suggests a 21 -fold improvement in the carbon intensity of the economy would be necessary by 2050. This, in turn, would require technological improvements to be implemented 10 times faster than current rates (2009:80). Jackson writes, the sheer scale of decoupling required to meet the limits set out ... staggers the imagination" (ibid 14). That said, Jackson concedes that the evidence does not "rule out the possibility entirely" if technological shifts are matched with rapid international diffusion, progressive policy and a "wholesale change" in consumer demand (2009: 75 emphasis ours).

\section{Beyond the green economy: discussion}

The need to compliment efficiency efforts with policies to address absolute consumption in the world's most affluent societies is well recognized by sustainable consumption scholars and international governance institutions (Dauvergne 2010, Princen 2002, Lorek and Fuchs, 2013, Hobson, 2013b). Yet the political precariousness of these ideas and the complex governance challenges associated with regulating international production processes have limited policy, even in one of the most environmentally progressive nations in the world, to the reinvention of consumer awareness campaigns and an international extension of decoupling strategies - both of uncertain efficacy.

Sweden's focus on Chinese production and consumption efficiencies, while neither unimportant nor inconsequential, constitutes an international extension of their long-standing emphasis on technological improvements and reaffirms the nation's commitment to decoupling. Efficiency gains are certainly an important part of the solution Laitner et al. (2012). But by focusing on Chinese producers, rather than Swedish consumers, the Swedish state has diverted attention away from the objective impacts of ongoing growth in consumer demand. Thus the question remains whether or not this "doubling down" on decoupling efforts will be enough to help Sweden achieve its generational goal. The claim that the economy can be separated from the environment is not well supported, particularly if we view consumption and production processes as interdependent and recognize that greenhouse gas emissions are not bound by geopolitical borders.

Current Swedish efforts to encourage consumers to reduce the energy, materials and emissions embodied in the products and services they buy are primarily channeled through informational labels and educational campaigns. Indeed, most consumptionbased studies like the Swedish EPA's "The Climate Impact of Swedish Consumption" have been utilized to increase consumer awareness while specific policy formation has taken "a secondary role" (Barrett, 2004:236). This trend has also been noted in the UK where the PIRC comments "it is particularly ironic given that while $75 \%$ of the UK's carbon footprint is associated with the products and services its citizens consume, official policy is focused overwhelmingly on the other 25\% of direct emissions" (PIRC, 2012:5).

Certainly Sweden is leading the international movement toward a greater recognition of the climate impact of consumption. Recently the Swedish EPA advocated "putting a price on adverse environmental impacts" and indicated that the Swedish Government has begun work on the valuation of ecosystem services (2012a:20). Yet it remains unclear how costs will be included in pricing mechanisms. A recent report suggested that policies to reduce meat consumption might include financial instruments such as a bonus malus tax intended to subsidize the price of less 
carbon intensive products with a tax on less favorable options (SEPA, 2011: 46). Several policy makers and scholars have also proposed carbon-based border tariffs designed to eliminate the competitive advantage of cheaper imports (O'Sullivan, 2012, Carmody, 2011). But these debates are contentious and seem unlikely to be resolved soon. Opponents claim they would restrict free trade and potentially result in significant export losses for developing countries (Mattoo et al., 2009). Proponents argue these WTO compliant measures (WTO, 2009) could be balanced by domestic GHG taxes (Monjon and Quirion, 2011) or fed back into the Clean Development Mechanism (Peters and Hertwich, 2008). Border adjustments would give consumers a better sense of the true costs of consumption while encouraging producers to innovate to remain competitive.

Despite these potential advantages, national governments have been hesitant to act unilaterally given the potential to damage trade. Sweden is a highly affluent and wealthy nation with one of the most competitive economies in the EU (World Economic Forum, 2010). Global competitiveness and economic growth are key priorities. While Sweden and many European nations have tempered their acceptance of free-market policies with robust state coordination (de Grazia, 2005, O'Dell, 1997), policies which limit the market or consumer choice are seen as an affront to the capitalist logics of competition, free choice, accumulation and growth and are thus politically precarious for elected officials.

\section{Conclusion}

We have argued that Swedish decoupling efforts, both at home and overseas, are unlikely to ensure the achievement of the "generational goal" without more ambitious and effective demandside policy. Consumption policy that moves beyond awareness campaigns and individualizing calls for smarter consumption have the potential to play a key role GHG mitigation strategies (Druckman and Jackson, 2010; Weber and Matthews, 2008) - affecting more emissions globally because they are so precisely targeted at the site of demand and highest impact (Peters, 2008; Sato, 2012). Policy ideas designed to reduce total consumption do exist (e.g. Deitz and O'neill, 2013, Fuchs and Lorek, 2005). In addition to pricing mechanisms that include the full ecological and social costs of production, policies ideas range from hard restrictions on the sale of single use and highly carbon-intensive products to investments in collaborative consumption, sharing economies, repair and redesign industries, and legal protections for product service agreements.

It is encouraging that consumption-based perspectives are driving significant discussions about the necessity for "stronger" sustainability policy. As Barrett and his colleagues write, "Even though consumption has been a long-neglected topic in dominant environmental discourse there are indications that it is now moving closer to the center of contemporary policy-making" (2006:246). The European Union's 7th Environmental Action Plan, for example, states that by 2020 "structural changes in production, technology and innovation, as well as consumption patterns and lifestyles have reduced the overall environmental impact of production and consumption, in particular in the food, housing and mobility sectors" (EU, 2013). This plan, like Sweden's generational goal, takes important new steps toward sustainable production and consumption by attempting to set targets for lifecycle environmental impacts from consumption (EEA, 2014). The EEA, in its 2014 Environmental Indicators Report, has already begun the work of developing indicators and policy recommendations for addressing consumption in three product sectors with significant climate impact: electronics, clothing and food (EEA, 2014).

While the suggestion that we need to reduce consumption may seem to have impractical economic implications, it certainly makes sense given what we know about the impracticality of continuing to dismiss the growing costs of ecological overshoot, resource degradation and the concentration of greenhouse gasses in our atmosphere. Further, as we hope has been made clear, displaced emissions are also linked to issues of justice. The evidence is mounting and is becoming increasingly hard to ignore. Consumption-based approaches support the assertion that affluent lifestyles and prosperity continue to be supported by the ability to outsource emissions, consume artificially cheap products, and allocate environmental consequences to those whose need for development leaves them with a constrained set of options.

Sweden has recognized this displacement and is attempting to move beyond the simplistic assumption that our economies can be separated from our natural resource base. Decoupling ideology, which paints environmental and economic policy as independent and unlinked, can be extremely misleading given the dual trend toward the dematerialization of industry yet increased importbased materialization of lifestyles in wealthy and environmentally progressive contexts. As long as environmental and economic policy are viewed as separate efforts, policies designed to protect our environment and ensure a sufficient level of consumption for the citizens of both developing and developed nations will likely continue to take a backseat to economic interests.

We don't suggest that any of these issues are straightforward or simple to solve. They are wicked problems in part because economic and environmental concerns are so intimately linked. For this reason we suggest that action in macro and trade policy is unlikely at least in the short term. Our point is that efficiency gains both at home and abroad, must be complimented by reduced consumption in the most affluent economies to allow for development where it is needed and to avoid dangerous climate change. Demand-side policies that encourage and incentivize repair and reuse, for example, make sense, would be relatively easy to implement and also provide economic and social benefit. They may result in some contraction, but of course a growing number of scholars argue that movement toward a steady state is wise for highly developed economies like Sweden's, at least until technological improvements catch up with growth.

\section{References}

Alfredsson, E.C., 2004. "Green" consumption-no solution for climate change. Energy $29,513-524$

Allaway, D., 2012. Sustainable Consumption: Opportunities and Challenges. In: Materials Management through Sustainable Consumption Webinar Series. US Department of Environmental Quality.

Atkinson, G., Hamilton, K., Ruta, G., Van Der Mensbrugghe, D., 2011. Trade in 'virtual carbon': empirical results and implications for policy. Glob. Environ. Change 21, $563-574$.

Attari, S.Z., Schoen, M., Davidson, C.I., DeKay, M.L., Bruine de Bruin, W., Dawes, R., Small, M.J., 2009. Preferences for change: do individuals prefer voluntary actions, soft regulations, or hard regulations to decrease fossil fuel consumption? Ecol. Econ. 68, 1701-1710.

Barrett, J., 2004. In: Hubacek, K., Inaba, A., Stagl, S. (Eds.), Proceedings of the International Workshop on Driving Forces of and Barriers to Sustainable Consumption. University of Leeds.

Barrett, J., Peters, G., Wiedmann, T., Scott, K., Roelich, K., Le Quere, C., 2013. Consumptionbased GHG emissions accounting: a UK case study. Clim. Policy 13, 451-470.

Berglund, M., 2011. Green Growth: a Consumption Perspective on Swedish Environmental Impact Trends Using Input-output Analysis. Global Energy Systems: Department of Physics and Astronomy, Uppsala University.

Boitier, B., 2012. CO 2 Emissions Production-based Accounting Vs. Consumption: Insights from the WOID Database. ERASME, Ecole Centrale Paris.

Bruckner, M., Polzen, C., Giljum, S., 2010. Counting $\mathrm{CO}_{2}$ Emissions in a Globalized World. German Development Institute, Bonn.

Buhr, K., Thörn, P., Hjerpe, M., 2012. The clean development mechanism in China: Institutional perspectives on governance. Environ. Policy Gov. 22, 77-89.

Carmondy, G., March 30, 2009. Can China Change the Coppenhagen Consultations? The National Forum. http://www.onlineopinion.com.au/view.asp?article=8733.

Carmody, G., 2011. Consumption-based emissions policy: a vaccine for the carbon pollution reduction scheme 'trade flu'? A Taxing Debate: Climate Policy Beyond Copenhagen. CEDA Growth Journal no 61. 
Connolly, J., Prothero, A., 2008. Green Consumption: life-politics, risk and contradictions. J. Consumer Cult. 8, 117-145.

Csutora, M., Mózner, Z., 2012. Rethinking kyoto compliance from a consumptionbased perspective. In: China-EU Cooperation for a Sustainable Economy. Corvinus University of Budapest, Aula, Budapest, pp. 177-200.

Dauvergne, P., 2010. The problem of consumption. Global Environ. Polit 10 (2), 1-10.

Davis, S.J., Caldeira, K., 2010. Consumption-based accounting of $\mathrm{CO}_{2}$ emissions. In: Proceedings of the National Academy of Sciences.

Davis, S.J., Peters, G.P., Caldeira, K., 2011. The supply chain of CO2 emissions. In: Proceedings of the National Academy of Sciences.

de Grazia, V., 2005. Irresistible Empire: America's Advance through 20th-Century Europe. Harvard.

Deitz, R., O'Neill, D., 2013. Enough is Enough: Building a Sustainable Economy in a World of Finite Resources. Berrett-Koehler Publishers, San Fransisco.

Druckman, A., Jackson, T., 2010. The bare necessities: how much household carbon do we really need? Ecol. Econ. 69, 1794-1804.

EEA, 2012a. Europe's Demand for Resources Reaching Far beyond its Borders. European Environment Agency.

EEA, 2012b. Unsustainable Consumption: the Mother of All Environmental Issues? European Environment Agency.

EEA, 2013. Trends and Projections in Europe 2013: Tracking Progress towards Europe's Climate and Energy Targets until 2020. European Environment Agency.

EEA, 2014. Environmental Indicators Report 2014: Environmental Impacts of Production and Consumption Systems in Europe. European Environment Aganecy.

Erickson, P., Chandler, C., Lazarus, M., 2012. Reducing Greenhouse Gas Emissions Associated with Consumption: a Methodology for Scenario Analysis. in Working Paper No. 2012-05. Stockholm Environmental Institute.

European Commission, Special Eurobarometer 409: Climate Change. Survey Carried Out in the 28 Member States between 23 November and 2 December 2013

European Commission, 2009a. Europeans' Attitudes toward Climate Change. European Commission.

European Commission, 2009b. Public Opinion in the European Union. European Commission, Brussels, Belgium.

Feng, K., Davis, S.J., Sun, L., Li, X., Guan, D., Liu, W., Liu, Z., Hubacek, K., 2013. In: Outsourcing $\mathrm{CO}_{2}$ within China. Proceedings of the National Academy of Sciences, vol. 110, pp. 11654-11659.

Foster, J.B., 2000. Marx's Ecology: Materialism and Nature. Monthly Review Press, New York.

Fuchs, D., Lorek, S., 2005. Sustainable consumption governance: a history of promises and failures. J. Consum. Policy 28, 261-288.

Froberg, M., Herodes, F., Jessup, F., Zingmark, A., 2013. Final Review of CENTEC, Center for Environmental Technology, at the Embassy of Sweden in Beijing, China. Swedish International Development Cooperation Agency, Stockholm.

Gullestad, M., 1989. Nature and everyday life in scandinavia. Folk 31, 171-181.

Halkier, B., 1999. Consequences of the politicization of consumption: the example of environmentally friendly consumption practices. J. Environ. Policy Plan. 1, 25-41.

Halkier, B., 2001. Consuming Ambivalences: consumer handling of environmentally related risks in food. J. Consumer Cult. 1, 205-224.

Hobson, K., 2013a. "Weak" or "Strong" Sustainable Consumption? Efficiency, Degrowth and the 10 Year Framework of Programmes.

Hobson, K., 2013b. On the making of the environmental citizen. Environ. Polit. 22 (1), 56-72.

Hoekstra, A.Y., Mekonnen, M.M., 2012. The water footprint of humanity. Proc. Natl. Acad. Sci. 109, 3232-3237.

Hornborg, A., 2009. Zero-sum world: challenges in conceptualizing environmental load displacement and ecologically unequal exchange in the world-system. Int. J. Comp. Sociol. 50, 237-262.

IEA, 2009. World Energy Outlook 2009. International Energy Agency.

Isenhour, C., 2010a. Building sustainable societies: a Swedish case study on the limits of reflexive modernization. Am. Ethnol. 37, 511-525.

Isenhour, C., 2010b. On conflicted Swedish consumers, the effort to stop shopping and neoliberal environmental governance. J. Consumer Behav. 9, 454-469.

Isenhour, C., 2012. The devil in the Deal: trade-embedded emissions and the Durban Platform. Ethics, Policy \& Environ. Special Issue Durb. Platf. 15, 303-308.

Jackson, T., 2009. Prosperity without Growth: Economics for a Finite Planet. Routledge, Abbington.

Jenkins, J., Nordhaus, T., Shellenberger, M., 2011. Energy Emergence. Breakthrough Institute.

Laitner, J.A., Nadel, S., Elliott, N., Sachs, H., Khan, S., 2012. The Long-term Energy Efficiency Potential: what the Evidence Suggests. American Council for an Energy-Efficient Economy (ACEEE), Washington, DC.

Leach, A.M., Galloway, J.N., Bleeker, A., Erisman, J.W., Kohn, R., Kitzes, J., 2012. A nitrogen footprint model to help consumers understand their role in nitrogen losses to the environment. Environ. Dev. 1, 40-66.

Lenzen, M., Moran, D., Kanemoto, K., Foran, B., Lobefaro, L., Geschke, A., 2012. International trade drives biodiversity threats in developing nations. Nature 486, $109-112$.

Löfgren, O., 1995. Being a good Swede. National Identity as a Cultural Battleground. In: Rapp, R., Schneider, J. (Eds.), Articulating Hidden Histories. University of California Press, Berkeley.

Lorek, S., Fuchs, D., 2013. Strong sustainable consumption governance: precondition for a degrowth path? J. Clean. Prod. 38, 36-43.

Martinez-Alier, J., 1987. Ecological Economics: Energy, Environment and Society. Blackwell, Oxford.
Matti, Simon, 2009. Exploring Public Policy Legitimacy: a Study of Belief-System Correspondence in Swedish Environmental Policy. Doctoral thesis Luleå: Luleå Tekniska Universitet.

Mattoo, A., Subramanian, A., der Mensbrugghe, D.V., He, J., 2009. Reconciling Climate Change and Trade Policy. World Bank.

Micheletti, M., 2003. Political Virtue and Shopping: Individuals, Consumerism, and Collective Action. Palgrave Macmillan, New York.

Mills, J.H., Waite, T.A., 2009. Economic prosperity, biodiversity conservation, and the environmental Kuznets curve. Ecol. Econ. 68, 2087-2095.

Monjon, S., Quirion, P., 2011. Which Design of a Border Adjustment for the EU ETS? A Quantitative Assessment. EAERE conference.

Munksgaard, J., Wier, M., Lenzen, M., Day, C., 2002. Indicators for the environmental pressure of consumption. In: Life-cycle Approaches to Sustainable Consumption - Workshop Proceedings. IIASA, Laxenburg, Austria.

Naturvårdverket, 2011. Köttkonsumtionens Klimatpåverkan: Drivkrafter Och Styrmede. Naturvårdverket, Stockholm.

New York Times, 2007. China rejects Criticism of its Carbon Emissions.

OECD, 2004. Indicators to Measure Decoupling of Environmental Pressure from Economic Growth. Organization for Economic Cooperation and Development.

OECD, 2013. Carbon Dioxide Emissions Embodied in International Trade. STAN Database.

O'Sullivan, J., 2012. Consumption - Based Emissions Accounting and Pricing: Harness Market Power to Enhance Mitigatiton. Position Paper submitted to the UNFCCC Secretariat March 5, 2012. http://unfccc.int/resource/docs/2012/smsn/ ngo/171.pdf.

O'Dell, T., 1997. Culture Unbound: Americanization and Everyday Life in Sweden. Nordic Academic Press, Lund.

Ölander, F., Thøgersen, J., 1995. Understanding of consumer behaviour as a prerequisite for environmental protection. J. Consum. Policy 18, 317-357.

Parliament, U., 2012. Consumption-based Emissions Reporting: Government Response to the Committee's Twelfth Report of Session 2010-12. Energy and Climate Change.

Peters, G.P., 2008. From production-based to consumption-based national emission inventories. Ecol. Econ. 65, 13-23.

Peters, G.P., Hertwich, E.G., 2008. $\mathrm{CO}_{2}$ embodied in international trade with implications for global climate policy. Environ. Sci. Technol. 42, 1401-1407.

Peters, G.P., Minx, J.C., Weber, C.L., Edenhofer, O., 2011. Growth in emission transfers via international trade from 1990 to 2008. Proc. Natl. Acad. Sci. 108, 8903-8908.

Peters, G.P., Davis, S.J., Andrew, R., 2012. A synthesis of carbon in international trade. Biogeosciences 9, 3247-3276.

Petherick, A., 2012. When carbon footprints hop. Nat. Clim. Change 2, 484-485.

PIRC - Public Interest Research Centre, 2012. Consumption-Based Emissions Reporting. Memorandum submitted by the Public Interest Research Centre to the UK Parliament.

Press, M., Arnould, E.J., 2009. Constraints on sustainable energy consumption: market system and public policy challenges and opportunities. J. Public Policy \& Mark. 28, 102-113.

Princen, T., Maniates, M., Conca, K., 2002. Confronting Consumption. The MIT Press, Cambridge, MA.

Public Interest Research Centre, 2011. Consumption-based Emissions Reporting Memorandum Submitted by the Public Interest Research Centre to the UK Parliament.

Rees, E., 2011. UK's Greenhouse Gas Emissions Reductions an 'Ilusion'. The Ecologist.

Sassatelli, R., 2006. Virgue, responsibility and consumer choice: framing critical consumerism. In: Brewer, J., Trentman, F. (Eds.), Consuming Cultures, Global Perspectives: Historical Trajectories, Transnational Exchanges. Berg, Oxford.

Sato, M., 2012. Embodied Carbon in Trade: a Survey of the Empirical Literature. Centre for Climate Change Economics and Policy, Grantham Research Institute. SEPA., 2011. Köttkonsumtionens Klimatepåverkan. SEPA, Stockholm.

SEPA, 2012a. Förslag till indikatorer för uppföljning av generationsmålet: underlag till den fördjupade utvärderingen av miljömålen 2012. SEPA, Stockholm.

SEPA, 2012b. Konsumtionsbaserade miljöindikatorer: Underlag för uppföljning av generationsmålet. SEPA, Stockholm.

SEPA, 2012c. Steg på vägen: Fördjupad utvärdering av miljömålen 2012. SEPA Stockholm.

SEPA, 2012d. Uppföljning av generationsmålet: Underlag till den fördjupade utvärderingen av miljömålen 2012. SEPA, Stockholm.

Shove, E., 2004. Comfort, Cleanliness, Convinience: the Social Organization of Normality. Bloomsbury Academic.

Shreck, A., 2008. Resistance, resdistribution, and power in the fair trade banana initiative. In: Wright, W., Middendorf, G. (Eds.), The Fight over Food: Producers Consumers, and Activists Challenge the Global Food System. Penn State University Press, University Park, PA.

Sjöström, M., Östblom, G., 2010. Decoupling waste generation from economic growth - A CGE analysis of the Swedish case. Ecol. Econ. 69, 1545-1552.

Söderholm, P., 2011. Sustainable Households: Environmental Policy and Everyday Sustainability Final Report to the Swedish Environmental Protection Agency from the SHARP Research Program. Naturvardsverket, Stockholm.

Spaargaren, G., 2003. Sustainable consumption: a theoretical and environmental policy perspective. Soc. Nat. Resour. 16, 687-701.

Stern, D.I., 2004. The rise and fall of the environmental Kuznets curve. World Dev. 32, 1419-1439.

TCO (The Swedish Confederation for Professional Employees), 2012. The Climate Transition and the Transition Climate: TCO's Rio ranking 2012:1. The Swedish Confederation of Professional Employees, Stockholm, Sweden. 
UK House of Commons Environmental Audit Committee, 2011. Carbon Budgets HC 1080. United Kingdom House of Commons, London.

UNEP, 2011. Decoupling Natural Resource Use and Environmental Impacts from Economic Growth, a Report of the Working Group on Decoupling to the International Resource Panel. United Nations Environment Program.

Weber, C.L., Matthews, H.S., 2008. Quantifying the global and distributional aspects of American household carbon footprint. Ecol. Econ. 66, 379-391.

Weidner, H., Mez, L., 2008. German climate change policy: a Success Story with some flaws. J. Environ. Dev. 17, 356-378.

Wiedmann, T., 2009. A review of recent multi-region input-output models used for consumption-based emission and resource accounting. Ecol. Econ. 69, $211-222$.

Wilk, R., 2010. Consumption embedded in culture and language: implications for finding sustainability. Sustain. Sci. Pract. Policy 6, 38-48.
Wilk, R., Wilhite, H., 1984. Household energy decision making. In: Kempton, W., Morrison, B. (Eds.), Families and Energy, Coping with Uncertainty. Michigan State University, Lansing, pp. 449-459.

WMO, 2013. Greenhouse Gas Concentrations in Atmosphere Reach New Record. World Meteorological Organization.

World Business Council for Sustainable Business, 2008. Sustainable consumption facts and trends. In: Business Role Focus Area (World Business Council for Sustainable Business) World Trade Organization.

World Economic Forum, 2010. Lisbon Review 2010: Toward a More Competitive Europe. World Economic Forum, Geneva, Switzerland.

World Trade Organization \& the United Nations Environment Program, 2009. Trade and Climate Change. World Trade Organisation, Geneva.

Xinhua News Agency, 2013. President Xi Pledges Not to Sacrifice Environment. http://news.xinhuanet.com/english/china/2013-05/24/c_132406763.htm. 